\title{
Ayurved for Skin Disorders, A Clinical Success Story of Guttate Psoriasis
}

\author{
Case Report
}

\section{Damini Sona1, Devendra Kumar Kunjam1, Prashant Kumar Gupta², Satyavati Rathiya ${ }^{4}$, Lowkesh Chandravanshi ${ }^{*}$}

1. PG Scholar, Department of Kaumarbhritya, NPA Government Ayurved College, Raipur. (C.G). India. 2. Faculty, Department of Kaumarbhritya, NPA Government Ayurved College, Raipur (C.G). India.

\begin{abstract}
Psoriasis is a chronic inflammatory papulo-squamous disorder of skin characterized by sharply defined erythematous-squamous lesion varying from pinpoint to large plaque, affecting 1-3\% of population worldwide. Psoriasis is well known for its course of remission and exacerbation. Here we report a case of 14-year-old male $42 \mathrm{~kg}$ weight, rotund physique child, diagnosed as Guttate psoriasis, Guttate psoriasis can be closely correlated with Ekkushtha (one of subtype of Kustha) in Ayurveda. Management of patient with, shodhan therapy (Biological purification of body) like mriduvirechan (Mild laxative) and shaman therapy (conservative therapy) showed remarkable improvement in patient condition. There is appreciable psychological health impairment found in patient, which adversely affect patient quality of life. This case study shows that Ayurveda line of treatment (Shodhan and shaman) gives significant result in the treatment of Guttate psoriasis.
\end{abstract}

Key Words: Ekkushtha, Guttate Psoriaisis, Shaman chikitsa, Mriduvirechan.

\section{Introduction}

Psoriasis is a non-infectious, chronic papulosquamous inflammatory disorder, mainly affecting skin and occasionally joints too $(1,2,3,4)$.Psoriasis is divided into 5 subtypes vulgaris (plaque), guttate, inverse, pustular and erythrodermic (5).Guttate psoriasis is particular form of cutaneous psoriasis generally affect children and young adults.Begins in childhood in almost $1 / 3$ of cases as independent or superimposed existing plaque psoriasis(6). Recurrent streptococcal infection triggers Guttate psoriasis $(6,7)$. The term "Guttate" refers "appearing as droplet" and clinically present with small, erythematous, squamous lesions over trunk and upper extremities, sooner appearance of psoriatic scales over lesions differentiates it from drug eruptive lesion. It is a complex multifactorial disease caused by interaction of immunological, genetic and environmental factors, like stress, excessive alcohol consumption and smoking. Paediatric psoriasis has been associated with certain comorbidities, such as obesity, hypertension, hyperlipidaemia, diabetes mellitus, and rheumatoid arthritis making its early diagnosis and management essential(8). In Ayurveda Guttate Psoriasis can be closely correlated with Ekkushtha (Psoriaisis), classical features of Ekkushtha mentioned in ancient

\section{* Corresponding Author:}

\section{Lowkesh Chandravanshi}

Faculty,

Department of Kaumarbhritya,

NPA Government Ayurved College,

Raipur (C.G). India.

Email Id: lowkeshc@gmail.com literature are Aswednam (Anhidrosis), Mahavastum (spread over large body surface), Matsya-Shaklopamam (appearance of the skin, resembles to silvery scales of fish) $(9,10,11)$. It is a disease of Tridosha with vatakapha (Psychobiological parameter of body) predominance. Nidana Parivarjna (avoidance of causative factors) Sanshodhan (Biological purification of body) and Sanshaman (Conservative treatment) therapies were done to manage such disorders. Here we are reporting a case summary of 14-year-old, $42 \mathrm{~kg}$ weight, male child, of rotund physique presents with the complaints of multiple erythematous silver scaly plaques at trunk and backside of the body. It is a Tridosha disease with vata-kapha (Psychobiological parameter of body) predominance. Nidana Parivarjna (avoidance of causative factors) Sanshodhan (Biological purification of body) and Sanshaman (Conservative treatment) therapies were done to manage such disorders, those diseases treated with shodhan does not recur, so to remove the accumulated doshas purification procedures like Vaman, virechan, ashthapan-basti should be done but contemplating the paediatric age group and sukumar-awastha only mriduvirechan (mild laxative) and shaman therapy (conservative treatment) been given.

\section{Presenting Complaints and medical history}

A 14-year, $42 \mathrm{~kg}$ body weight, male child residing in rural area, came to OPD of Government Ayurvedic Hospital Raipur (c.g) (12 December 2019) with complaints of multiple erythematous silver scaly plaques at trunk and backside of the body for 3 years, also had complaint of sleep disturbance due to severe itching for 6 months, occasional history of constipation for 6 months. Past 
history row same illness since November 2016, initially he visited a family doctor (20 November 2016) and took some anti-fungal drugs orally and topical application for 2 months with no relief. No clinical flare-up or retreat was observed during the expert treatment (dermatologist) from 2017 to 2018. Then the patient reported to our Out Patient Department for Ayurvedic treatment with the same complaints.

\section{Clinical Findings}

Patient presented with irregular, erythematous, silver scaly plaques over trunk and hips with no swelling, discharge, pulsation, tenderness, fluctuation, or temperature. On examination, patient was well oriented to time place and person. Signs like pallor, icterus, cyanosis or clubbing, Lymphadenopathy were absent. Vital were stable and growth \&amp; developmental milestones were attained corresponding to age. On Skin examination, plaque diameter was 0.3 $\mathrm{cm}-0.5 \mathrm{~cm}$, multiple erythematous lesions, irregular, hard margin and itchy in nature. No significant physical and systemic deformity was observed.

\section{Diagnostic Focus and assessment}

On the basis of previous History, medical documents, and presenting sign and symptom, patient was provisionally diagnosed Guttate Psoriasis and diagnosed as Ekkushtha in Ayurveda. Psoriasis is clinically diagnosed and usually a skin biopsy not require.Classically kushtha mentioned under Raktapradoshaj-vikar, clinical features of Ekkushtha are, Aswednam (Anhidrosis), Mahavastum (spread over large body surface), Matsya-Shaklopamam (appearance of the skin, resembles to silvery scales of fish),these features are equivalent to features of Guttate psoriasis, therefore provisional diagnosis of patient was made as Guttate psoriasis.

\section{Therapeutic focus and assessment \\ MriduVirechan(Mild Luxative)}

Ekkushtha is a Tridoshaj-vikar with kapha predominance (According to Acharya Sushrut) and vata-kapha predominance (According to Acharya Charak). Kapha and vata-kapha predominant disease were treated via Vaman therapy (Vomiting) but contemplating the paediatric age group and sukumar awastha mridu-virechan (mild laxative) advised instead of Vaman therapy.Virechan helps to eliminate the aggravated doshas from body, via pacifying pitta and kapha it reduces scaling, itching and discolouration. Hence we planned to give mild laxative (MriduVirechan with avipattikar choorna and erand oil) for first 7 days.

\section{Deepan-pachan(Appetizer and Digestive)}

Tab Agnitundi vati given as deepen-pachan drug, it will promote absolute digestion and assimilation of food as well as medicines taken, so we will get proper action of medication.

\section{Internal Medication}

All medicine was given are used in skin disorders according to Ayurveda, some of this medicines helps to purify the blood, which will help to suppress itching and restore the normal texture of skin, some medicines shows anti-inflammatory property, as inflammation plays an important role in pathology of psoriasis in order that, these medicines used will interrupt the pathology of disease.

\section{Local Application}

Gandhak oil has a dioxide gas that releases a distinct odour. Benefits of sulfur pertaining to psoriasis and psoriatic arthritis, Sulfur lowers toxins in the body. Sulfur eases itching caused by psoriasis. Melanocyte proliferation stimulants are of interest as potential treatments for the depigmentary skin disorder. Piper nigrum L. (Piperaceae) water extract and its main alkaloid, piperine, promote melanocyte proliferation.

\section{Follow up and outcomes}

Follow up has been done regularly, but as from last week of March 2020 complete lockdown was imposed on India due to COVID-19 Pandemic hence no more follow-up was continued. This case study shows that Ayurveda line of treatment (Shodhan \& Shaman) gives significant result in the treatment of Guttate Psoriaisis.

Table 1: Timelines of events

\begin{tabular}{|c|c|c|c|c|c|}
\hline S.no & $\begin{array}{l}\text { Date of } \\
\text { Consultation }\end{array}$ & Symptoms & Clinical findings & Investigation & Treatment Given \\
\hline 1 & 12.12.2019 & $\begin{array}{l}\text { Itching, } \\
\text { multiple } \\
\text { erythematous } \\
\text { Lesions } \\
\text { at trunk and } \\
\text { backside of the } \\
\text { body, Sleep } \\
\text { disturbance } \\
\text { constipation }\end{array}$ & $\begin{array}{l}\text { On skin examination } \\
\text { irregular, } \\
\text { erythematous, silver } \\
\text { scaly plaques are } \\
\text { present on the trunk } \\
\text { and hips. Plaque } \\
\text { diameter was } 0.3 \mathrm{~cm} \text { - } \\
0.5 \mathrm{~cm} \text {, irregular, hard } \\
\text { edge, Other signs like } \\
\text { swelling, discharge, } \\
\text { pulsation, tenderness, } \\
\text { fluctuation, } \\
\text { temperature are } \\
\text { absent. }\end{array}$ & $\begin{array}{l}\text { Patient was not } \\
\text { willingfor } \\
\text { investigation }\end{array}$ & $\begin{array}{l}\text { Erand oil } 15 \mathrm{ml} \text { at night with } \\
\text { Avipattikar choorna } 3 \text { gm, } \\
\text { Agnitundi vati } 2 \text { tab at morning in } \\
\text { empty stomach }\end{array}$ \\
\hline
\end{tabular}




\begin{tabular}{|c|c|c|c|c|c|}
\hline 2 & 20.12.2020 & $\begin{array}{l}\text { No more } \\
\text { complain of } \\
\text { constipation } \\
\text { while other } \\
\text { symptoms were } \\
\text { persisting }\end{array}$ & $\begin{array}{l}\text { On skin examination. } \\
\text { Irregular, } \\
\text { erythematous, plaques } \\
\text { are present on the } \\
\text { trunk and hips. Other } \\
\text { signs like swelling, } \\
\text { discharge, pulsation, } \\
\text { tenderness, } \\
\text { fluctuation, } \\
\text { temperature are } \\
\text { absent. }\end{array}$ & $\begin{array}{l}\text { Patient was not } \\
\text { willingfor } \\
\text { investigation }\end{array}$ & $\begin{array}{l}\text { Tablet Gandhak Rasayan: } 1 \text { Tab BD } \\
\text { Panchatiktadi Ghrita Guggulu: } 5 \\
\text { gm TID with luke warm water } \\
\text { Manjisthadi kwath: } 20 \mathrm{ml} \text { TID } \\
\text { ArogyavardhaniVati2 Tab TID } \\
\text { Khadirarishta } 20 m l \text { TID } \\
\text { Formulation prepared: Abhrak } \\
\text { bhasma 65mg + Kaishor guggulu } \\
\text { 125mg+Rasmanikya 62.5mg+Rajat } \\
\text { Bhasma } 15 \text { mg+Trikatu choorna } \\
\text { 500mg twice a day with honey } \\
\text { For local application: Gandhak oil } \\
\text { and Marichyadi oil twice daily }\end{array}$ \\
\hline 3 & 04.01.2020 & $\begin{array}{l}\text { Itching is mild } \\
\text { compare to } \\
\text { previous } \\
\text { follow-up, } \\
\text { Patient started } \\
\text { getting good } \\
\text { sleep at night } \\
\text { multiple } \\
\text { erythematous } \\
\text { Lesions } \\
\text { at trunk and } \\
\text { backside of the } \\
\text { body }\end{array}$ & $\begin{array}{l}\text { Irregular, } \\
\text { erythematous, plaques } \\
\text { are present on the } \\
\text { trunk and hips, lesions } \\
\text { were smooth, Edges } \\
\text { were flat, lesions } \\
\text { embossed at the level } \\
\text { of skin }\end{array}$ & $\begin{array}{l}\text { Patient was not } \\
\text { willing for } \\
\text { investigation }\end{array}$ & $\begin{array}{l}\text { Tablet Gandhak Rasayan: } 1 \text { Tab BD } \\
\text { Panchatiktadi Ghrita Guggulu: } 5 \\
\text { gm TID with luke warm water } \\
\text { Manjistadi kwath: } 20 \text { ml TID } \\
\text { Arogyavardhani Vati2 Tab TID } \\
\text { Khadirarishta } 20 m l \text { TID } \\
\text { Formulation prepared: Abhrak } \\
\text { bhasma } 65 \mathrm{mg}+\text { Kaishor guggulu } \\
\text { 125mg+Rasmanikya } 62.5 m g+\text { Rajat } \\
\text { Bhasma } 15 \text { mg+Trikatu choorna } \\
\text { 500mg twice a day with honey } \\
\text { For local application: Gandhak oil } \\
\text { and Marichyadi oil twice daily }\end{array}$ \\
\hline 4 & $19 / 01 / 2020$ & $\begin{array}{l}\text { Itching } \\
\text { isabsent, } \\
\text { multiple } \\
\text { Brownish } \\
\text { lesions were } \\
\text { present at trunk } \\
\text { and back side } \\
\text { of the body }\end{array}$ & $\begin{array}{l}\text { Hyper pigmented skin } \\
\text { lesions were present, } \\
\text { edges at the level of } \\
\text { skin, smooth, no other } \\
\text { signs are present. }\end{array}$ & $\begin{array}{l}\text { Patient was not } \\
\text { willing for } \\
\text { investigation }\end{array}$ & $\begin{array}{l}\text { Tablet Gandhak Rasayan: } 1 \text { Tab BD } \\
\text { Panchatiktadi Ghrita Guggulu: } 5 \\
\text { gm TID with luke warm water } \\
\text { Manjisthadi kwath: } 20 \text { ml TID } \\
\text { ArogyavardhaniVati2 Tab TID } \\
\text { Khadirarishta } 20 m l \text { TID } \\
\text { Formulation prepared: Abhrak } \\
\text { bhasma } 65 \mathrm{mg}+\text { Kaishor guggulu } \\
\text { 125mg+Rasmanikya } 62.5 m g+\text { Rajat } \\
\text { Bhasma } 15 \text { mg+Trikatu choorna } \\
\text { 500mg twice a day with honey } \\
\text { For local application: Gandhak oil } \\
\text { and Marichyadi oil twice daily }\end{array}$ \\
\hline 5 & $06 / 02 / 2020$ & $\begin{array}{l}\text { Symptoms } \\
\text { were reduced } \\
\text { compare to } \\
\text { previous } \\
\text { follow-up }\end{array}$ & $\begin{array}{l}\text { Lesions start getting } \\
\text { brownish color }\end{array}$ & $\begin{array}{l}\text { Patient was not } \\
\text { willingfor } \\
\text { investigation }\end{array}$ & $\begin{array}{l}\text { Tablet Gandhak Rasayan: } 1 \text { Tab BD } \\
\text { Panchatiktadi GhritaGuggulu: } 5 \\
\text { gm TID with lukewarm water } \\
\text { Manjistadi kwath: } 20 \mathrm{ml} \text { TID } \\
\text { ArogyavardhaniVati } 2 \mathrm{Tab} \text { TID } \\
\text { Khadirarishta } 20 \mathrm{ml} \text { TID } \\
\text { Formulation prepared: Abhrak } \\
\text { bhasma } 65 \mathrm{mg}+\text { Kaishor gugulu } \\
\text { 125mg+Rasmanikya } 62.5 m g+\text { Rajat } \\
\text { Bhasma } 15 \text { mg+Trikatu choorna } \\
\text { 500 mg twice a day with honey } \\
\text { For local application: Gandhak oil } \\
\text { and Marichyadi oil twice daily }\end{array}$ \\
\hline 6 & $20 / 02 / 2020$ & $\begin{array}{l}\text { almost } \\
\text { symptom free }\end{array}$ & $\begin{array}{l}\text { There are only } \\
\text { brownish marks of } \\
\text { lesions of same size } \\
\text { are present, clinically } \\
\text { complete healed out. } \\
\text { Skin color starts } \\
\text { getting normal }\end{array}$ & $\begin{array}{l}\text { Patient was not } \\
\text { willingfor } \\
\text { investigation }\end{array}$ & $\begin{array}{l}\text { Tablet Gandhak Rasayan: } 1 \text { Tab BD } \\
\text { Panchatiktadi GhritaGuggulu: } 5 \\
\text { gm TID with luke warm water } \\
\text { Manjisthadi kwath: } 20 \text { ml TID } \\
\text { ArogyavardhaniVati2 Tab TID } \\
\text { Khadirarishta } 20 m l \text { TID } \\
\text { Formulation prepared: Abhrak } \\
\text { bhasma } 65 \text { mg + Kaishor guggulu } \\
\text { 125mg+Rasmanikya } 62.5 m g+\text { Rajat } \\
\text { Bhasma } 15 \text { mg+Trikatu choorna } \\
\text { 500mg twice a day with honey } \\
\text { For local application: Gandhak oil } \\
\text { and Marichyadi oil twice daily }\end{array}$ \\
\hline
\end{tabular}


Figure 1

$12 / 12 / 2019$

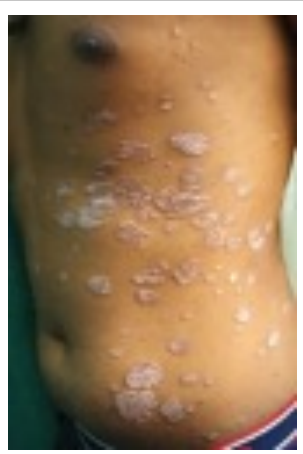

$19 / 01 / 2020$

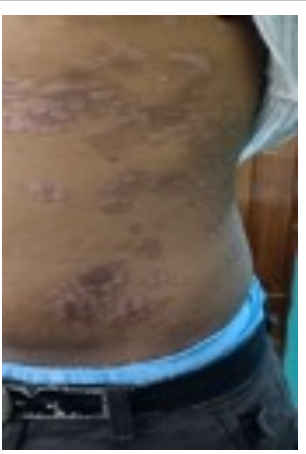

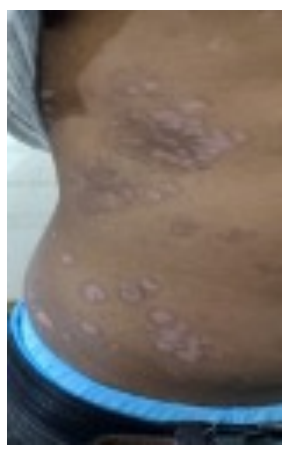

$20 / 02 / 2020$

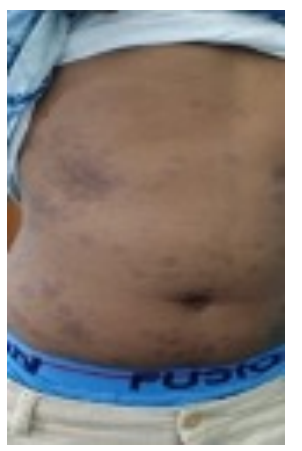

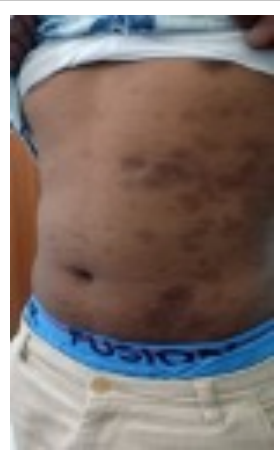

\section{Discussion}

Psoriasis is a chronic disease with frequent relapse and need long duration medication. Currently there is no definite cure of Psoriasis, but can be medically treated for the betterment of quality of life of patient, as in these disease patient not only present with physical manifestations, there is significant mental and psychological health impairment, these aggregate deleterious effect on patient social wellbeing and work performance. Arogyavardhani vati (12) is a polyherbomineral preparation advised for skin disorders, Its constituents are shuddha parad (Herbal purified Mercury), shuddha gandhak (Herbal purified sulphur), lauh-bhashma (Ash prepared from iron), Tamrabhashma (Ash prepared from copper), Haritaki (Terminalia chebula Retz.), Vibhitaki (Terminalia bellarica Roxb.), Amalki (Emblica officinale Gaertn.), Shilajatu (Ashphaltum), Guggulu (Commiphora mukul Hook and Stocks), Chitramoola (Plumbago zeylanica Linn.), Katuki (Picrorhiza kurroa Royal ex Benth) and Nimbswaras (juice of Azadiracta indica A. Juss), various studies supporting the antibacterial and antifungal activity of Arogyavardhani vati. Plenty of Triphala in Arogyavardhanivati is very beneficial to eliminate the Amatoxin (Undigested form of food) from the body. In pathology of psoriasis there is sustained inflammation resulting into unchecked keratinocytes proliferation and malfunctioned differentiation, as inflammation plays an important role in the pathology of psoriasis, the anti-inflammatory and potent analgesic properties of the medicine is extremely beneficial in treating skin disease. Being loaded with antioxidant, Arogyavardhini vati scavenges free radicals from body and prevent the deleterious effect of disease on body, its antipruritic activity alleviates itching. Gandhak rasayan(13) shows various properties such as, antiviral, anti-bacterial, anti-inflammatory and anti-pruritic. Infectious events are major triggering factor in occurrence of guttate psoriasis, so due to anti-bacterial activity of gandhak rasayan, it may alleviate symptoms of guttate psoriasis, similarly because of anti-pruritic activity it helps to relief from itching.Its mechanism of action as per Ayurveda, Gandhak rasayan help to sustain the optimum status of Raktadhatu (Blood) also act as Rasayan (Rejuvenator), due to its swedjanana (Induce Perspiration) activity, it removes Pitta and kapha dosha (Humours) from the body, and because of Kandughan (Antipruritic) property, it alleviates itching. Panchtikta ghrita guggulu(14) an herbal preparation generally advised for skin disorder boosts with the goodness of five better herbs viz. Nimb, giloy, kantkarri, patola, vasa along with ghrit and guggulu. Nimbidin a chemical constituent present in Nimb (Azadiracta indica) possess antiulcer and dose dependent anti-inflammatory activity. Berberin and tinosporin found in Guduchi (Tinospora cordifolia Willd) have anti-oxidant and immuno-modulating activity. Vascicinone present in Vasa (Adhatoda vasica Nees) have anti-inflammatory, anti-histaminic and antioxidant properties, Ghrit possess lipophilic activity which helps in ion transportation to the target organ, facilitates drug entry to the cell and drug delivery to mitochondria, microsomes and nuclear membrane, also helps in re-establishing texture of normal skin. Due to all these properties, these compound will act at the cellular level of skin \& check the uncontrolled proliferation of keratinocytes, hence use of these compound reduce symptoms of disease. Its mechanism of action according to Ayurveda, as most of the contents of this compound are tiktaras (Bitter taste), laghu (Lightness) and ruksha guna (Dryness), it mollifies pitta and kapha dosha, and also works on lasika (Interstitial fluid), rakta (Blood), meda (Adipose tissue) and sweda (Sweat). Manjisthadi kwatha(15) Its major constituent is Manjistha (Rubia cordifolia Linn) rich in anthraquinones like purpurin, munjistin, rubiasin and mollugin has anti-inflammatory, analgesic, and antioxidant properties. As sustained inflammation plays an important role in pathology of psoriasis therefore these compound is useful in interrupting pathology of disease. As per Ayurveda Manjistha has Raktshodhak (blood purify) property and it pacify pitta dosha. Marichyadi tail(16) has antiseptic, antifungal, antiinflammatory, and immuno-modulatory property hence use of these preparation will deplete the symptoms of psoriasis. As per Ayurveda, mechanism of action of Marichyadi tail it reduces rukshta (Dryness), kharata (Roughness) it also possess rakta-shodhak (Blood purifier) Kandughna (Anti-pruritic) property, in combination, the induration of lesion as well as scaling was significantly decreased. Thickness and scaling are caused due to vitiation of Kaphadosha. Khadiraristha 
(17), major constituent is Khadir (Acacia catechu Willd.) which pacify kapha dosha, its chemical constituents are quercetin, fiscetin, epicatechin, and other important tannins. Catechu is reported to regulate cytotoxic T-cells. Fiscetin shows hepato-protective activity, Quercetin a compound reported to inhibits histamine release and tannin acts as the vasoconstrictor. Hence the mentioned pharmacological actions are collectively potent to counteract the inflammatory autoimmune reactions as occurs in Psoriasis. Khadira is tikta-kashaya rasa (bitter and astringent taste), these two rasa by the virtue of their pharmacological properties like Soshana (Drying up), Vishaghnatva (anti-poisonous), Kandu-prashamana (reduce itching sensation), ropana (wound healing), Tvakmamsasthirikarana (nourishment and strengthening of skin and muscle), Kleda-upashosana (dry of exudation) and pidana (Medicated paste applied all over wound except at opening), all these therapeutic activity leads to reduce edema, detoxification of body, antihistaminic action, clearing of derbies, contraction, healing of wound and restoration. Thus these pharmacological properties as a whole are able to exert an antiinflammatory action on the affected areas of skin, which is beneficial to cure psoriasis, especially during active lymphocyte infiltration. Rasamanikya (18) is an efficient Ayurvedic formulation with properties to manage the disease occurring due to vitiation of vata and kapha dominance skin disorders. Rasamanikya (an arsenical formulation) contains Haratala (arsenic trisulphide) as an integral component, Arsenic has been highly liable for production of interleukin- $1 \beta$ in murine keratinocyte cell line (HEL30) though, these have been used safely in Ayurvedic clinical practice since ages without any noticeable unanticipated effects; there is need to generate scientific evidence that these are safe and nontoxic. Combined effects of these drugs are helpful in interrupting the immunological reaction, removal of a toxic substance from the body, relieving pain, inflammation, infection, alleviate itching and improve general body condition. The combination of these drugs has the potential to alleviate all the manifestations of Psoriasis.

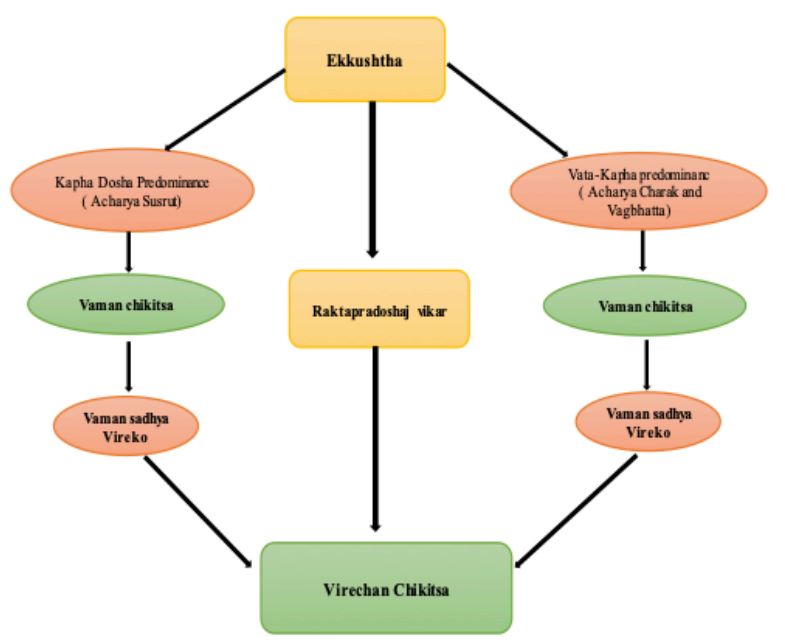

Figure :- 2

\section{Conclusion}

Shodhan and shaman therapy based on Ayurvedic principle had shown marked improvement in all symptoms of psoriasis, hence it is evident that this management will produce significant result in psoriasis, such result provide hope to many who are suffering from psoriasis, limitation of these case report is single case study and need to be studied in more number of patients for its concrete evidence.

As per ancient literature Kustha is mentioned under Raktapradoshaj-vikar, virechan chikitsa (Therapuetic Purgation) is the main line of treatment for Raktapradoshaj-vikar, According to pathology of disease it is a Tridosh ojvikar with Vata-kapha predominance according to Acharya Charak, Acharya Vagbhatta and Kapha predominance according to Acharya Susrut, Vaman-chikitsa is the one treatment for Kapha and Vata-kapha predominance disorder, contemplating the pediatric age group and Sukumar awstha, Virechan-chiktsa is advised instead of Vaman chiktsa because Vaman-chikitsa is contraindicated in pediatric age group, Hence, Virechan karma was planned for the better treatment of Ekkushtha (Figure 04).

\section{References}

1. Parveen Kumar, Michael Clark. Clinical Medicine. $6^{\text {th }}$ ed. Spain; Elsevier Saunders; 2005. 1331-34p.

2. GunjanMangal, GopeshMangal, and RadheShyam Sharma. Clinical efficacy of Shodhan Karma and Shaman Karma in Mandala Kushtha (Psoriasis). Ayu.2012 Apr-Jun; 33(2): 224-229.

3. Nicki R. Colledge, Brian R. Walker, Stuart H. Ralston. Davidson's Principles \& Practice of Medicine 21st ed. China; Elsevier; 2011.1260-65p.

4. Dan L. Longo, Anthony S. Fauci, Dennis L. Kasper, Stephen L. Hauser, J. Larry Jameson, Joseph Loscalzo. Harrison's Principles of Internal Medicine. 18th edition. Mc Graw Hill Medical; 2012. 398-99p.

5. Nilmarie Ayala-Fontanez, David C Soler, Thomas S McCormick. Current knowledge on psoriasis and autoimmune diseases 22 feb 2016.

6. Roxane Pinson, Bahman Sotoodian, and Loretta Fiorillo, Psoriasis in children 20 Oct 2016.

7. Gwendy Dupire, Catherine Droitcourt, Crolyn Hughes, Laurence Le Cleach. Antistreptococcal intervention for guttate and chronic plaque psoriasis. Cochrane library; 05 March 2019.

8. Augustin M, Glaeske G, Radtke M A, Christophers E, Reich K, Schafer I. Epidemiology and comorbidity of psoriasis in children. mar. 2010.

9. BrahmanandaTripathi. Charak Samhita of Acharya Charak.Varanasi; Chaukhamba Sanskrit Sansthan; 2012. 305p.

10. BrahmanandaTripathi. AstangaHrdayam of Acharya SrimadVagbhata. Delhi;Chaukhamba Sanskrit Pratisthan; 2009. 529-30p.

11. Bulusu Sitaram. Bhavpraksah of Bhavmishra. Varanasi; Chaukambha Orientalia; 2015. 531p. 
12. Siddhi Nandan Mishra. Bhaisajya Ratnavali of Shri Govinddassen. Varanasi; Chaukhamba Surbharati Prakashan; 2012. 871p.

13. Siddhi Nandan Mishra. BhaisajyaRatnavali of Shri Govinddassen. Varanasi; Chaukhamba Surbharati Prakashan; 2012. 882p.

14. Siddhi Nandan Mishra. BhaisajyaRatnavali of Shri Govinddassen. Varanasi; Chaukhamba Surbharati Prakashan; 2012. 867p.

15. Siddhi Nandan Mishra. BhaisajyaRatnavali of Shri Govinddassen. Varanasi; Chaukhamba Surbharati Prakashan; 2012. 871p.
16. Siddhi Nandan Mishra. BhaisajyaRatnavali of Shri Govinddassen. Varanasi; Chaukhamba Surbharati Prakashan; 2012. 889p.

17. Siddhi Nandan Mishra. BhaisajyaRatnavali of Shri Govinddassen. Varanasi; Chaukhamba Surbharati Prakashan; 2012. 895p.

18. Siddhi Nandan Mishra. BhaisajyaRatnavali of Shri Govinddassen. Varanasi; Chaukhamba Surbharati Prakashan; 2012. 872p. 